\title{
Respons Sitokin Interferon Gamma Terhadap Derajat Infeksi Skabies pada Kelinci
}

\author{
(RESPONSE OF INTERFERON GAMMA CYTOKINE \\ TO THE SEVERITY OF SCABIES INFECTION IN RABBITS) \\ Amirotul Azhimah ${ }^{1}$, Nunuk Dyah Retno Lastuti ${ }^{*}$, \\ Thomas Valentinus Widiyatno ${ }^{3}$, Lucia Tri Suwanti ${ }^{2}$, \\ Poedji Hastutiek ${ }^{2}$, Hani Plumeriastuti ${ }^{3}$. \\ ${ }^{1}$ Mahasiswa Program Magister \\ Ilmu Penyakit Kesehatan Masyarakat Veteriner \\ ${ }^{2}$ Divisi Parasitologi Veteriner \\ ${ }^{3}$ Divisi Patologi Anatomi Veteriner \\ Fakultas Kedokteran Hewan, Universitas Airlangga \\ Kampus C Unair, Jalan Mulyorejo, Kota Surabaya, \\ Jawa Timur, Indonesia, 60115 \\ Telepon $+6281226094872,5993016 ;$ Faksimili +62315993015 \\ email:nunukdyah53@gmail.com
}

\begin{abstract}
Scabies is an infectious skin disease caused by Sarcoptes scabiei. The role of IFN- $\gamma$ on hypersensitivity reactions of scabies with different severity has not been widely reported. This study was aim to determine the role of cytokine IFN- $\gamma$ in the inflammatory process and the degree of skin damage in relation to the severity of scabies infection in rabbits, so that we can determine the pathogenesis reaction of scabies in rabbits. A total of 24 rabbits that are naturally infested with S. scabiei used in this study. The rabbits were divided into four groups based on the size of the lesion and the thickness of the scales caused by scabies infection: Group 1: control negative, Group 2: Rabbits infected with mild scabies, Group 3: moderate scabies, and Group 4: severe scabies. An immunohistochemistry examination was performed on each group using IFN- $\gamma$ antibody. The result of the study showed that affected IFN-ã expression which was indicated by the different intensity of brownish color change on the skin tissue of rabbits infected with scabies with mild, moderate, and severe degree. Statistical analysis using Kruskal Wallis test showed that there was a significant difference on cytokine IFN- $\gamma$ expression in mild scabies, moderate scabies, and severe scabies $(\mathrm{P}<0.05)$. The conclusion is, in more severe scabies infection, the expression of IFN- $\gamma$ to increase.
\end{abstract}

Keywords: immunohistochemistry; scabies; Sarcoptes scabiei; IFN- $\gamma$

\begin{abstract}
ABSTRAK
Skabies merupakan penyakit kulit menular yang disebabkan oleh tungau Sarcoptes scabiei. Peran IFN- $\gamma$ terhadap reaksi hipersensitivitas skabies dengan tingkat keparahan yang berbeda belum banyak dilaporkan. Penelitian ini bertujuan untuk mendeteksi peran sitokin IFN- $\gamma$ pada proses peradangan dan tingkat kerusakan kulit akibat derajat infeksi skabies pada kelinci sehingga dapat diketahui lebih lanjut mengenai reaksi patogenesis skabies pada kelinci. Sebanyak 24 ekor kelinci yang secara alami terinfeksi S. scabiei digunakan dalam penelitian ini. Penelitian ini mengelompokkan hewan coba menjadi empat kelompok berdasarkan luasan lesi dan ketebalan krusta akibat infeksi skabies, yaitu: kelompok kontrol, skabies ringan, skabies sedang, dan skabies berat. Setiap kelompok dilakukan pemeriksaan imunohistokimia menggunakan antibodi IFN- $\gamma$. Hasil penelitian menunjukkan bahwa derajat infeksi skabies berpengaruh terhadap ekspresi sitokin IFN- $\gamma$ yang ditunjukkan dengan intensitas perubahan warna kecoklatan yang berbeda pada jaringan kulit kelinci yang terinfeksi skabies ringan, skabies sedang, dan skabies berat. Uji statistika dengan uji Kruskal Wallis menunjukkan bahwa terdapat perbedaan yang nyata pada ekspresi sitokin IFN- $\gamma$ terhadap skabies ringan, skabies sedang, dan skabies berat $\mathrm{P}<0,05)$. Simpulan dari penelitian ini yaitu semakin berat derajat infeksi skabies, ekspresi IFN- $\gamma$ semakin meningkat
\end{abstract}

Kata-kata kunci: imunohistokimia; scabies; IFN- $\gamma$; derajat infeksi 


\section{PENDAHULUAN}

Skabies merupakan penyakit yang banyak menyerang ternak, bahkan dapat menyerang manusia atau bersifat zoonosis (Bhat et al., 2017; Lastuti et al., 2018). Skabies menyebabkan masalah kesehatan global sebagai penyakit menular. Penularannya dapat terjadi melalui kontak langsung antar hewan penderita. Tingkat hygiene dan sanitasi yang relatif rendah menjadi faktor pemicu terjangkitnya penyakit skabies serta kondisi kandang yang sempit, lembap, dan berdesakan semakin mempermudah penularan penyakit skabies dari hewan yang terinfeksi kepada hewan yang sehat (Azhimah et al., 2018).

Patogenesis skabies berhubungan dengan respons imun dari inang yang diawali dengan penetrasi tungau $S$. scabiei yang akan menembus kulit hingga mencapai stratum korneum, kemudian menghisap cairan getah bening dan mereduksi sel epidermis untuk kelangsungan hidup. Aktivitas tungau $S$. scabiei tersebut menyebabkan iritasi, rasa gatal terus menerus, terbentuk eritema, papula, vesikula dan akhirnya, terjadi reaksi inflamasi yang diikuti oleh pembentukan eksudat. Eksudat akan mengendap di permukaan kulit sehingga terbentuk kerak dan penebalan pada kulit (Arlian dan Morgan, 2017; Lastuti et al., 2019). Mekanisme pemicu gejala klinis terkait dengan reaksi hipersensitivitas tipe I dan IV, dan diduga tungau S. scabiei menghasilkan antigen yang mengaktifkan reaksi hipersensitivitas tipe 1 untuk menghasilkan IL-10 sebagai antiinflamasi dan penekan reaksi kekebalan (Walton et al., 2010; Lastuti et al., 2018). Respons imun terhadap infeksi parasit S. scabiei didefinisikan sebagai respons yang dimediasi oleh sel Th1 atau Th2 namun, dari penelitian sebelumnya terungkap bahwa respons imun dari inang terhadap skabies berkrusta dimediasi oleh sel Th2, dan skabies ringan dimediasi oleh sel Th1. Reaksi imun Th1 didominasi oleh CD4+ dan CD8+ yang mensekresi IFN- $\gamma$ dan IL-2. Sel Th2 yang mensekresi IL-4, IL-5 dan IL-13 adalah sel efektor yang dominan dalam patogenesis hipersensitivitas yang dimediasi IgE (Walton, 2010a).

Walton et al. (2010) mengungkapkan bahwa terjadi penurunan aktivasi Th 1 untuk memproduksi IFN- $\gamma$, IL- 2 , dan TNF pada kejadian skabies berat. Hal ini terjadi akibat sitokin IL-10 menghambat sintesis sitokin proinflamasi IFN- $\gamma$ dan IL-2, sehingga timbul gejala klinis skabies yang tak terlihat selama 4-6 minggu setelah infeksi tungau S. scabiei.

Berdasarkan latar belakang tersebut, IFNã berperan terhadap reaksi hipersensitivitas skabies, sehingga perlu dilakukan penelitian untuk mendeteksi respons sitokin IFN- $\gamma$ pada skabies bergejala ringan, sedang, berat. Tujuan dari penelitian ini untuk mengetahui peran sitokin IFN- $\gamma$ pada proses peradangan akibat derajat infeksi skabies pada kelinci.

\section{METODE PENELITIAN}

Sampel yang digunakan pada penelitian berjumlah 24 ekor kelinci dari ras New Zealand yang didapat dari peternakan kelinci di Kota Kediri, Jawa Timur dan terinfeksi skabies secara alami. Kelinci tersebut dikelompokkan menjadi empat kelompok yaitu : Kelompok 1: kelompok kelinci kontrol negatif (kelinci normal); Kelompok 2: kelompok kelinci yang terinfeksi skabies ringan; Kelompok 3: kelompok kelinci yang terinfeksi skabies sedang; dan Kelompok 4: kelompok kelinci yang terinfeksi skabies berat. Penelitian ini menggunakan jaringan kulit telinga kelinci yang positif skabies yang digunakan untuk pemeriksaan imunohistokimia untuk melihat ekspresi sitokin IFN$\gamma$.

Kriteria pengambilan sampel kelinci yang terinfeksi skabies ringan, skabies sedang, dan skabies berat berdasarkan gambaran makroskopis distribusi dan luas dari krusta, serta ketebalan krusta berdasarkan Davis et al. (2013). Kelinci yang terinfeksi skabies ringan dengan distribusi dan luas krusta terdapat pada pergelangan kaki, kulit di antara jari kaki, kaki ( $<10 \%$ total area permukaan tubuh), ketebalan krusta $<5 \mathrm{~mm}$, kondisi kulit tidak ditemukan likenifikasi dan alopecia. Kelinci yang terinfeksi skabies sedang dengan distribusi dan luas krusta terdapat pada pergelangan kaki, kulit di antara jari kaki, kaki, telinga, pantat, punggung atau tubuh bagian tengah (10-30\% total area permukaan tubuh), ketebalan krusta $5-10 \mathrm{~mm}$, kondisi kulit ditemukan beberapa pustula. Kelinci yang terinfeksi skabies berat dengan distribusi dan luas krusta terdapat pada pergelangan kaki, kulit di antara jari kaki, telinga, pantat, punggung atau tubuh bagian tengah, area kepala (sekitar mata, hidung atau moncong) ( $>30 \%$ total area permukaan tubuh), ketebalan krusta $>10 \mathrm{~mm}$, kondisi kulit 
mengalami likenifikasi, alopecia, dan kadang terjadi perdarahan.

\section{Hewan Coba}

Penggunaan hewan coba untuk penelitian skabies telah dilakukan uji etik melalui Tim Komisi Etik Fakultas Kedokteran Hewan Universitas Airlangga, dengan sertifikat No. 630-KE. Kelompok kontrol dan kelompok yang positif terinfeksi skabies ringan, skabies sedang dan skabies berat, semua kelompok kelinci tersebut dilakukan pengambilan jaringan kulit telinga kelinci sekitar $1 \mathrm{x} 1 \mathrm{~cm}^{2}$ untuk koleksi sampel dengan prosedur sesuai uji etik penggunaan hewan coba.

\section{Identifikasi Sarcoptes scabiei}

Identifikasi S. scabiei menggunakan metode skin scraping dilakukan dengan pengerokan kulit telinga kelinci yang diduga menderita skabies mulai dari kelinci yang terinfeksi skabies ringan, skabies sedang, dan skabies berat. Hasil kerokan tersebut ditambahkan dengan larutan $\mathrm{KOH} 10 \%$ dan diletakkan pada object glass, kemudian ditutup dengan cover glass dan diperiksa melalui mikroskop stereo dengan perbesaran 30 kali.

\section{Pembuatan Preparat Imunohistokimia}

Pembuatan preparat imunohistokimia diawali dengan merendam jaringan kulit yang telah dipotong berukuran kurang lebih $1 \mathrm{x} 1 \mathrm{~cm}^{2}$. dalam larutan phosphate buffer saline (PBS) 10\% untuk fiksasi. Pembuatan preparat imunohistokimia menggunakan Kit LSAB dari Dako (LSAB-2 System peroxidase universal kit, DAKO, No. K 0672, Denmark). Preparat yang sudah mengalami proses deparafin dibilas aquades (dengan cara ditetesi) dan diinkubasi selama 10 menit Selanjutnya preparat dibilas dengan PBS (semua proses pencucian dilakukan dengan cara diteteskan) dan diinkubasi selama 10 menit. Tahap berikutnya preparat dietesi peroksidase (kit), diinkubasi selama 15 menit. Kemudian, preparat dibilas dengan PBS (semua proses pencucian dilakukan dengan cara diteteskan) dan diinkubasi selama 10 menit (diulangi lagi sebanyak tiga kali). Selanjutnya preparat ditetesi $100 \mu \mathrm{L}$ Triton X 1\% + FBS 2\% dalam PBS per blok, diinkubasi selama 45 menit, disimpan dalam boks tertutup. Kemudian preparat dibilas dengan PBS (semua proses pencucian dilakukan dengan cara diteteskan) dan diinkubasi selama 10 menit (diulangi lagi sebanyak tiga kali). Langkah berikutnya preparat ditetesi antibodi primer poliklonal IFNã, di inkubasi $4^{\circ} \mathrm{C}$ selama satu malam (disimpan dalam boks). Selanjutnya, preparat dibilas dengan PBS (semua proses pencucian dilakukan dengan cara diteteskan) dan diinkubasi selama 10 menit (diulangi lagi sebanyak tiga kali). Kemudian, preparat ditetesi $100 \mu \mathrm{L}$ antibodi sekunder (Biotinylated link) per blok, diinkubasi selama dua jam, disimpan didalam boks selanjutnya preparat dibilas dengan PBS (semua proses pencucian dilakukan dengan cara diteteskan) dan diinkubasi selama 10 menit (diulangi lagi sebanyak tiga kali). Tahap berikutnya Preparat ditetesi $100 \mu \mathrm{L}$ conjugate (strepavidin) per blok, diinkubasi selama 40 menit, disimpan dalam boks. Selanjutnya preparat dibilas dengan PBS (semua proses pencucian dilakukan dengan cara diteteskan) dan diinkubasi selama 10 menit (diulangi lagi sebanyak tiga kali) setelah dibilas preparat ditetesi $50 \mu \mathrm{L}$ DAB per blok, diinkubasi selama 20 menit, simpan dalam boks tertutup, DAB dibuang dan preparat dibilas dengan PBS (semua proses pencucian dilakukan dengan cara diteteskan) dan diinkubasi selama 10 menit (diulangi lagi sebanyak tiga kali). Langkah terakhir preparat ditetesi dan dibilas aquades, diinkubasi selama lima menit. Kemudian ditetesi dan dibilas air kran, diinkubasi selama lima menit, selanjutnya ditetesi meyer haematoxilin, diinkubasi selama 8-10 menit, tetesi dibilas aquades mengalir sampai meyer haematoxilin bersih, lalu dikeringkan dan dianginkan (Taylor dan Rudbeck, 2013).

\section{Analisis Data}

Pemeriksaan dengan metode imunohistokimia yaitu memeriksa jaringan yang mengalami perubahan menjadi merah kecoklatan yang menandakan bahwa terdapat ekspresi dari sitokin pada jaringan kulit yang diamati. Pemeriksaan dilakukan menggunakan mikroskop binokuler dengan perbesaran 100 kali. Intensitas pewarnaan dari sitokin IFN- $\gamma$ dikelompokkan menjadi lima kelompok: negatif (sel tidak berwarna coklat) skor 0, weak (d"25\% sel berwarna coklat) skor 1 , moderate $(25-50 \%$ sel berwarna coklat) skor 2 , strong $(50-75 \%$ sel berwarna coklat) skor 3 , dan very strong (e" $75 \%$ sel berwarna coklat) skor 4 (Nassef et al., 2015). Hasil pengolahan data disajikan setelah diuji dengan menggunakan uji Kruskal-Wallis. 


\section{HASIL DAN PEMBAHASAN}

Hasil pemeriksaan dengan metode imunohistokimia menunjukkan terdapat pengaruh respons sitokin IFN- $\gamma$ terhadap derajat infeksi skabies pada kelinci mulai dari kontrol negatif, skabies ringan, skabies sedang, dan skabies berat. Kelompok kontrol ternyata menunjukkan ekspresi sitokin IFN- $\gamma$ yang lemah. Ekspresi sitokin IFN- $\gamma$ pada kelompok kelinci kontrol dapat dilihat dari sebagian lapisan dermis yang mengalami perubahan warna coklat sedangkan, untuk lapisan epidermis, folikel rambut, dan kelenjar sebasea tidak mengalami perubahan warna coklat. Ekspresi IFN- $\gamma$ tetap muncul pada kelompok kelinci kontrol karena IFN- $\gamma$ diproduksi secara terus menerus dalam kondisi normal atau sehat oleh mukosa jaringan limfoid yang terkena sejumlah agen xenobiotic yang dapat berfungsi sebagai penginduksi IFN- $\gamma$ (Pollard et al., 2018).

Kelompok kelinci yang terinfeksi skabies ringan menunjukkan ekspresi sitokin IFN- $\gamma$ yang lemah. Ekspresi sitokin IFN- $\gamma$ pada kelompok kelinci yang terinfeksi skabies ringan dapat dilihat dari sebagian lapisan dermis yang mengalami perubahan warna coklat sedangkan, untuk lapisan epidermis tidak menunjukkan ekpresi sitokin IFN- $\gamma$ yang ditandai dengan terwarnai biru. Kelenjar sebasea dan folikel rambt juga tidak mengalami perubahan warna coklat. Infeksi skabies ringan pada kelinci merupakan infeksi tahap awal yang biasanya berlangsung kurang lebih selama satu sampai dua minggu (Bhat et al., 2017). Respons imun dari infeksi skabies ringan dimediasi oleh sel Th 2 yang mensekresi IL-4 yang berperan terhadap pematangan sel B untuk menstimulasi produksi antibodi IgE. Sekresi IL-4 dan IgE yang dominan pada infeksi skabies ringan dapat menghambat pengeluaran IFN- $\gamma$ (Morgan dan Arlian., 2010) sehingga, pada skabies ringan ditemukan ekpresi IFN- $\gamma$ yang lemah.

Kelompok kelinci yang terinfeksi skabies sedang menunjukkan ekspresi sitokin IFN- $\gamma$ dengan tingkat staining sedang. Hal tersebut menunjukkan bahwa terjadi peningkatan ekspresi IFN- $\gamma$ dari infeksi skabies ringan ke infeksi skabies sedang. Ekspresi sitokin IFN- $\gamma$ pada infeksi skabies sedang dapat dilihat dari lapisan epidermis yang mengalami perubahan warna coklat, perubahan warna coklat terjadi pada bagian stratum granulosum hingga stratum spinosum. Sebagian lapisan dermis mengalami perubahan warna coklat serta beberapa kelenjar sebasea dan folikel rambut mengalami perubahan warna coklat. Peningkatan ekspresi sitokin IFN- $\gamma$ terlihat dari lapisan epidermis yang mulai menunjukkan perubahan warna menjadi coklat berbeda dengan ekspresi sitokin IFN- $\gamma$ pada skabies ringan yang hanya mengalami perubahan warna coklat pada lapisan dermis. Lapisan epidermis menunjukkan ekspresi IFN- $\gamma$ karena IFN- $\gamma$ merupakan sitokin yang berperan dalam sistem imun alami dan sistem imun adaptif (Locati et al., 2013) sehingga, pada sistem imun alami sel dendritik yang merupakan sel langerhans yang terdapat pada stratum spinosum akan mengaktivasi sel NK untuk memproduksi IFN- $\gamma$ yang akan mengaktifkan makrofag. IFN- $\gamma$ juga berperan menghambat apoptosis keratinosit, terjadinya hiperproliferasi keratinosit dan merangsang proliferasi sel epidermis (Wardhana et al., 2018). Aktivitas keratinosit dan sel langerhans oleh sitokin IFN- $\gamma$ sebagai bentuk pertahanan diri dari inang untuk melawan antigen tungau sehingga, mengakibatkan peningkatan sekresi sitokin IFN- $\gamma$ (Al-Musawi et al., 2018).

Kelompok kelinci yang terinfeksi skabies berat menunjukkan ekspresi sitokin IFN- $\gamma$ dengan tingkat staining sedang meskipun, menghasilkan tingkat staining yang sama dengan infeksi skabies sedang, namun pada uji statistika menggunakan Kruskal Wallis terdapat perbedaan yang nyata antara skabies sedang dengan skabies berat. Hal tersebut menandakan bahwa terjadi peningkatan ekspresi sitokin IFN- $\gamma$ pada infeksi skabies berat namun, dari hasil skoring pemeriksaan imunohistokimia, peningkatan ekspresi sitokin IFN- $\gamma$ pada kelompok skabies berat tidak terjadi pada semua sampel dari keenam ekor kelinci yang terinfeksi skabies berat. Hanya dua sampel atau dua ekor kelinci dari kelompok skabies berat yang menunjukkan peningkatan ekspresi sitokin IFN- $\gamma$, keempat ekor kelinci dari skabies berat tidak menunjukkan peningkatan ekspresi sitokin IFN- $\gamma$. Ekspresi sitokin IFN- $\gamma$ dapat dilihat dari lapisan epidermis yang mengalami perubahan warna coklat, perubahan warna coklat terjadi pada bagian stratum korneum yang mengalami parakeratosis dan stratum granulosum. Sebagian besar lapisan dermis mengalami perubahan warna coklat. Beberapa folikel rambut mengalami perubahan warna coklat sedangkan, untuk kelenjar sebasea tidak mengalami perubahan warna coklat.

Derajat infeksi skabies yang semakin berat 
mengharuskan adanya keseimbangan respons imun yang dimediasi oleh sel T. Sitokin yang dihasilkan oleh sel Th 2 yaitu IL- 4 dan IL-13 akan menghambat aktivasi makrofag yang dihasilkan oleh sitokin IFN-ã, sehingga, mengakhiri reaksi yang berpotensi marusak jaringan (Cope et al., 2011). Sitokin IL-4 dan IL-13 juga mengaktifkan makrofag untuk mensekresikan faktor pertumbuhan yang bekerja pada fibroblas untuk meningkatkan sintesis kolagen dan menginduksi fibrosis. Respons makrofag tipe ini disebut sebagai aktivasi makrofag alternatif(Justin et al., 2011). Fungsi dari fibrosis adalah sebagai faktor angiogenesis, proliferasi fibroblas, deposisi matriks ekstraseluler, dan remodelling sehingga, dengan adanya proliferasi fibroblas menyebabkan kulit telinga kelinci yang
Tabel 1. Uji statistika rata-rata nilai skoring terhadap pemeriksaan imunohistokimia pada jaringan kulit telinga kelinci akibat perbedaan derajat infeksi skabies

\begin{tabular}{lrr}
\hline \multirow{2}{*}{$\begin{array}{l}\text { Derajat } \\
\text { Infeksi }\end{array}$} & \multicolumn{2}{c}{$\mathrm{X} \pm \mathrm{SE}$} \\
\cline { 2 - 3 } & IFN- $\gamma$ & Rank of IFN- $\gamma$ \\
\hline Kontrol & $1,0 \pm 0,0$ & $5,5^{\mathrm{a}} \pm 0,0$ \\
Ringan & $1,0 \pm 0,2$ & $9,2^{\mathrm{b}} \pm 0,0$ \\
Sedang & $2,0 \pm 0,0$ & $16,5^{\mathrm{c}} \pm 0,0$ \\
Berat & $2,0 \pm 0,2$ & $18,8^{\mathrm{d}} \pm 0,0$ \\
\hline
\end{tabular}

Keterangan: a,b,c,d Superskrip yang berbeda pada kolom yang sama menunjukkan perbedaan yang nyata $(p<0,05)$

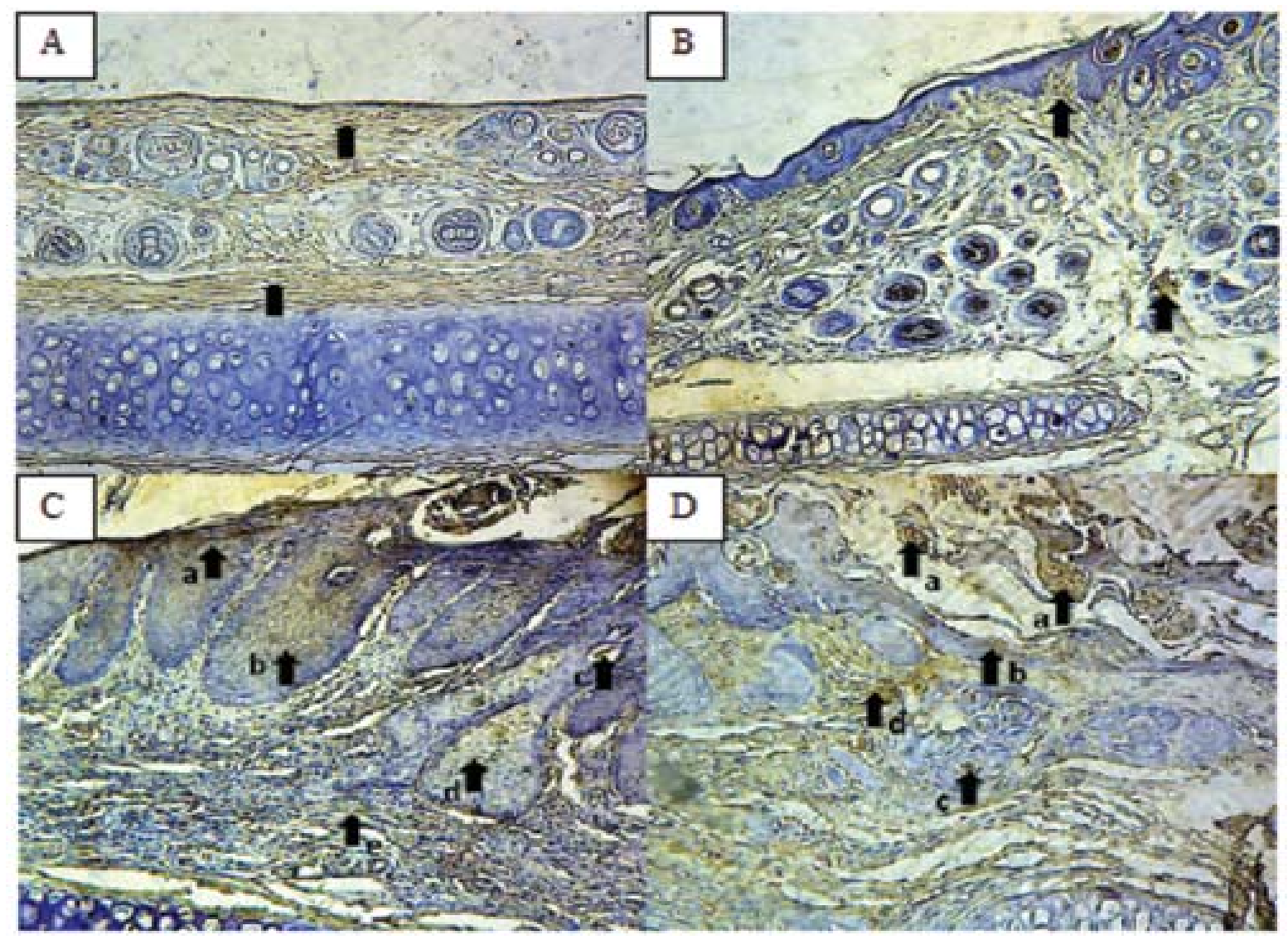

Gambar 1. [A] kelinci kontrol menghasilkan staining lemah. tanda panah adalah sel yang mengekspresikan IFN-ã. [B] Kelinci yang terinfeksi skabies ringan menghasilkan staining lemah, tanda panah adalah sel yang mengekspresikan IFN-ã. [C] Kelinci yang terinfeksi skabies sedang menghasilkan staining sedang, tanda panah adalah sel yang mengekspresikan IFN-ã yang ditemukan pada: (a) stratum granulosum, (b) stratum spinosum, (c) folikel bulu, (d) kelenjar sebasea, (e) lapisan dermis. [D] Kelinci yang terinfeksi skabies berat menghasilkan staining sedang, tanda panah adalah sel yang mengekspresikan IFN-ã yang ditemukan pada: (a) stratum korneum, (b) stratum granulosum,(c) folikel rambut, (d) lapisan dermis. Perbesaran 100 kali. Pengamatan dilakukan dengan mikroskop Nikon ${ }^{\circledR}$ E-100. 
terinfeksi skabies berat semakin menebal (Johnson dan Dipietro, 2013). Keseimbangan respons imun juga diatur oleh sel T regulator. Peran dari sel T regulator adalah menghambat aktivasi sel $\mathrm{T}$ dan diferensiasinya menjadi sel $\mathrm{T}$ efektor dengan mensekresi sitokin IL-10 dan TGF-â yang menghambat aktivasi limfosit, sel dendritik, dan makrofag (Abbas et al., 2017). TGF-â merupakan sitokin yang bersifat imunosupresor yaitu menekan respons inflamasi yang berpotensi merusak jaringan. Ekspresi TGF-â telah diteliti menggunakan metode imunohistokimia bahwa terjadi peningkatan ekspresi TGF-â pada infeksi skabies yang berat. Peningkatan ekspresi TGF-â pada skabies berat berguna untuk menekan respons inflamasi yang berpotensi merusak jaringan dengan cara menekan pengeluaran sitokin proinflamasi seperti IL-2 dan IFN-ã (Rizki et al., 2018). Aktivitas tersebut mungkin terjadi sebagai faktor ekspresi IFN-ã, namun pada skabies berat mengalami peningkatan yang tidak signifikan. Ekspresi sitokin IFN-ã pada infeksi skabies berat mengalami peningkatan yang tidak signifikan juga telah diteliti sebelumnya menggunakan peripheral blood mononuclear cells (PBMCs) pada babi bahwa terjadi peningkatan yang signifikan terhadap ekspresi IFN-ã pada minggu pertama, sedangkan ketika infeksi skabies pada babi telah berjalan lama respons dari IFN-ã tidak mengalami peningkatan yang signifikan (Liu et al., 2014). Respons sitokin IFN-ã terhadap perbedaan derajat infeksi skabies pada kelinci ditunjukkan pada Gambar 1.

Hasil uji statistika rata-rata nilai skoring terhadap pemeriksaan imunohistokimia pada jaringan kulit telinga kelinci akibat perbedaan derajat infeksi skabies disajikan pada Tabel 1. Hasil uji statistika dengan uji Kruskal Wallis menunjukkan bahwa terdapat perbedaan yang nyata pada ekspresi sitokin IFN-ã terhadap kelinci kontrol, kelinci yang terinfeksi skabies ringan, skabies sedang, dan skabies berat $(\mathrm{P}<0,05)$.

\section{SIMPULAN}

Sitokin IFN-ã berpengaruh terhadap derajat infeksi skabies pada kelinci. Berdasarkan pemeriksaan dengan metode imunohistokimia ekspresi sitokin IFN-ã cenderung meningkat sampai derajat infeksi skabies berat.

\section{SARAN}

Perlu dilakukan penelitian lebih lanjut terhadap sitokin antiinflamasi, seperti sitokin IL-4, IL-10, dan IL-17 yang mekanisme kerja dari sitokin tersebut berlawanan dengan sitokin proinflamasi.

\section{UCAPAN TERIMA KASIH}

Penulis mengucapkan terima kasih kepada Fakultas Kedokteran Hewan, Universitas Airlangga atas kesempatan yang diberikan untuk mengikuti pendidikan magister di Program Studi S2 Ilmu Penyakit dan Kesehatan Masyarakat Veteriner.

\section{DAFTAR PUSTAKA}

Abbas AK, Lichtman AH, Pillai S. 2017. Basic Immunology: Functions and Disorders of the Immune System. Philadelphia. Saunders Elsevier. Hlm. 239-256.

Al-Musawi ND, Al-Bayati NY, Hussain M. 2018. Evaluation of Some Interleukins and Immunomodulatory Factors in Iraqi Scabies Patients. Journal of Garmian University 5(2): 30-40.

Arlian LG, Morgan MS. 2017. A Review of Sarcoptes scabiei: Past, Present and Future. Parasites \& Vectors 10: 297.

Azhimah A, Lastuti NDR, Arimbi, Legowo D, Hastutiek P, Yustinasari LR. 2018. Comparative Histopathologic Changes in Rabbit (Oryctolagus cuniculus) (Mammalia: Lagomorpha: Leporidae) Skin in Relation to Degree of Infestation with Sarcoptes scabiei (Arachnida: Acari: Sarcoptidae). Philippine Journal of Veterinary Medicine 55(1): 1-14.

Bhat SA, Mounsey KE, Liu X, Walton SF. 2017. Host Immune Responses to the Itch Mite, Sarcoptes scabiei, In Humans. Parasites \& Vectors 10: 385.

Cope A, Friec GL, Cardone J, Kemper C. 2011. The Th 1 life cycle: Molecular Control of IFNã to IL-10 Switching. Trends in Immunology 32(6): 278-286. 
Davis JS, Gloughlin MC, Tong SYC, Walton SF, Currie BJ. 2013. A Novel Clinical Grading Scale to Guide the Management of Crusted Scabies. PLOS Neglected Tropical Diseases 7(9): 1-5.

Johnson A, Dipietro LA. 2013. Apoptosis and Angiogenesis: an Evolving Mechanism for Fibrosis. The Faseb Journal 27: 3893-3901.

Justin I, Degaard O, Chawla A. 2011. Alternative Macrophage Activation and Metabolism. Annu Rev Pathol 6: 275-297.

Lastuti NDR, Hastutiek P, Suwanti LT, Chrismanto D. 2018. Exploration of Sarcoptes scabiei Antigenic Protein which Play Roles in Scabies Pathogenesis in Goats and Rabbits. Iran J Parasitol 13(3): 466472.

Lastuti NDR, Rohman A, Handiyatno D, Chrismanto D, Desiandura K. 2019. Sequence analysis of the cytochrome c oxidase subunit 1 gene of Sarcoptes scabiei isolated from goats and rabbits in East Java, Indonesia. Veterinary World 12(7): 959-964.

Liu X, Walton SF, Murray HC, King M, Kelly A, Holt DC, Currie BJ, Mccarthy JS, Mounsey KE. 2014. Crusted Scabies is Associated with Increased IL-17 Secretion by Skin T Cells. Parasite Immunology 36: 594-604.

Locati M, Mantovani A, Sica A. 2013. Chapter Six - Macrophage Activation and Polarization as an Adaptive Component of Innate Immunity. Advances in Immunology 120: 163-184.

Morgan MS, Arlian LG. 2010. Response of Human Skin Equivalents to Sarcoptes scabiei. Journal of Medical Entomology 47: 877-883.
Nassef NE, El-Nahas NS, El-Din SAS, Matar AM. 2015. Assessment of Different Diagnostic Methods For Scabies With Follow-Up of Cellular Immune Response. Menoufia Medical Journal 28: 627-634.

Pollard KM, Christy JM, Cauvi DM, Kono DH. 2018. Environmental Xenobiotic Exposure and Autoimmunity. Current Opinion in Toxicology 10: 15-22.

Rizki SM, Lastuti NDR, Suwanti L. 2018. Histochemical Expression of Transforming Growth Factor Beta and Tumor Necrosis Factor Alpha in Rabbits (Oryctolagus cuniculus) (Mammalia: Lagomorpha: Leporidae) Infected with Sarcoptes scabiei (Arachnida: Acari: Sarcoptidae). Philippine Journal of Veterinary Medicine 55: 43-50.

Taylor C, Rudbeck L. 2013. Dako's Guidebook to Immunohistochemical Staining Methods. Dako 6: 78-91.

Walton SF, Pizzutto S, Slender A, Viberg L, Holt D, Hales BJ, Kemp DJ, Currie BJ, Rolland JM, Hehir RO. 2010. Increased Allergic Immune Response to Sarcoptes scabiei Antigens in Crusted versus Ordinary Scabies. Clinical and Vaccine Immunology 17(9): 1428-1438.

Walton SF. 2010a. The Immunology of Susceptibility and Resistance to Scabies. Parasite Immunology 32(8): 532-540.

Wardhana M, Suryawati N, Praharsini IGAA, Indira EIGAA. 2018. Hubungan Antara Kadar Serum Interferon Gamma dengan Derajat Keparahan Psoriasis Vulgaris. Media Dermato Venereologica Indonesiana 45(4): 178-181. 